\title{
Short Communication: \\ Ethnozoology - The perception of Tobelo Dalam tribal community in Saolat Village, East Halmahera, Indonesia towards cuscus (Phalangeridae)
}

\author{
ELIZABETH NOVI KUSUMANINGRUM ${ }^{1}$, JATNA SUPRIATNA ${ }^{2}$, ABINAWANTO ${ }^{2, \vartheta}$, ANOM BOWOLAKSONO² \\ ${ }^{1}$ Program of Conservation Biology, Department of Biology, Faculty of Mathematics and Natural Sciences, Universitas Indonesia. Jl. Lingkar UI, E \\ Building UI Campus, Depok 16242, West Java, Indonesia. \\ ${ }^{2}$ Department of Biology, Faculty of Mathematics and Natural Sciences, Universitas Indonesia. Jl. Lingkar UI, E Building UI Campus, Depok 16242 , \\ West Java, Indonesia. Tel.: +62-21-7270163, Fax.: +62-21-78829010, `email: abinawanto.ms@sci.ui.ac.id
}

Manuscript received: 5 July 2018. Revision accepted: 1 November 2018.

\begin{abstract}
Kusumaningrum EN, Supriatna J, Abinawanto, Bowolaksono A. 2018. Short Communication: Ethnozoology - The perception of Tobelo Dalam tribal community in Saolat Village, East Halmahera, Indonesia towards cuscus (Phalangeridae). Biodiversitas 19: 2140-2146. The complexity of the hard lives of Tobelo Dalam tribal community who live in Saolat village, district South Wasile provokes the high activity of animal poaching in Aketajawe-Lolobata National Park (TNAL) including cuscus hunting for both sale and consumption purposes. The study aimed to describe the traditional knowledge of Tobelo Dalam people in Saolat village in applying the systems of utilization and local conservation knowledge towards cuscus. This study was analyzed by the qualitative method with explorative survey technique, interview, and completing questionnaires. This study used 4 key informants ( 3 males, 1 female) and 50 adult respondents ( 25 males and 25 females). The results showed that the average percentage of traditional knowledge owned by males and females were $69.1 \%$ and $30.9 \%$, respectively, so the males had an advantage of knowledge around $38.3 \%$ than females in addressing the traditional knowledge of cuscus. The community of Tobelo Dalam tribe hunts cuscus for four different purposes, i.e., for traditional ceremonies, traditional medicine, cuisine, and sell it for more income to support the economy of family.
\end{abstract}

Keywords: Cuscus, East Halmahera, etnozoology, Phalangeridae, Tobelo Dalam tribal community

\section{INTRODUCTION}

The integration of traditional beliefs, the way of thinking, and the perception towards the living environment are emerged in the traditional knowledge keeping from generation to generation. Traditional knowledge can be used as the principles of natural resource management because it has contributed greatly to environmental conservation and sustainable use. One of the most interesting traditional knowledge to study is in many ways the elders of the Tobelo tribe who are familiar with nature, magic, and all aspects of traditional knowledge have given the names of all animals they know and until now the name is still used because some are considered popular or have been the correct name (i.e. at least those large enough to be easily visible with the naked eye must have had at least one correct name). But if there is an animal species that the Tobelo people do not know by name now, this is because of their lack of close knowledge with the low magical and magical powers they have (Taylor 1990). The naming of animal nomenclature and the classification are based on the paradigm, perception, and traditional society concept. Both perception and traditional society concept are early phases and foundation for traditional knowledge on animal behavior and ecology in the study of interaction between man and animal, both domestic and wild animals and the term is called ethnozoology (Hunn 2011; Alves and Souto 2015).

The distribution of marsupials which belong to Phalangeridae covers from Australia to Papua New Guinea. Four out of six genera which are in the family and endemic in eastern Indonesia (Flannery et al. 1997, McNab 2008). Halmahera island is one of the regions which has a certain distribution of cuscus from Phalanger genus. Cuscus is marsupial which has a marsupium (MacDonald et al. 1993; Nowak 1999), and is a nocturnal animal (MacDonald et al.1993; Latinis 1996; Flannery 1997; Heinsohn 1998; Nowak 1999; Helgen 2007), arboreal (Nowak 1999; Helgen and Flannery 2004), eat leaves, fruits, flowers, barks and ocassionally insects (Latinis 1996). According to IUCN Red List, cuscus is listed as least concern while CITES listed it as Appendix II.

Throughout history it is recognized that Tobelo Dalam tribal community is primitive. It has been shown by its community characters which is considered as an early age civilization such as loincloths, bare feet, dark complexion, long hair, and uncombed (Saluang 2014). Tobelo Dalam tribal community in Saolat village, district of South Wasile, East Halmahera District has a unique culture in their daily lives. Geographically, Saolat village is located not far from the primary forest about $2-3 \mathrm{~km}$ which is famous for the high population of cuscus in National Park AketajaweLolobata (TNAL). 


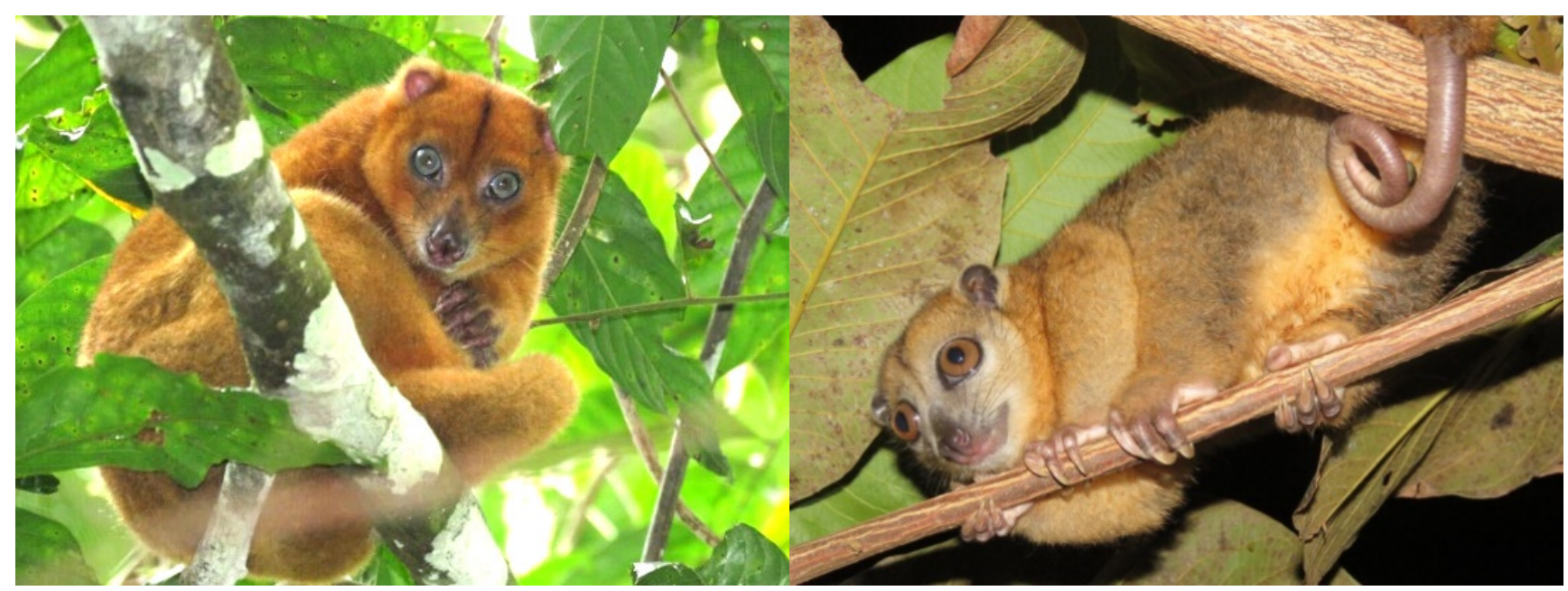

Figure 1. Cuscus (Phalanger ornatus)

Saolat villagers live in the rapid development of communication technology online based. The spirit to have better life never ends and never fades from its social characters. However, the condition is not supported by the demographic data of its community such as education. They reach junior high school at the most, their livelihood as a fisher, copra farmer who work in others' land. They gain coconuts from surrounding land near TNAL forest. The income level of the community is relatively low while the living cost is very high. The Central Bureau of Statistics stated that Halmahera island is in the third position of the high living cost, the living cost in Ternate reaches Rp 6.4 million/per month (BPS 2017).

The complexity of the living conditions of the Tobelo Dalam tribal community in Saolat Village can drive the increase of wildlife hunting activities including cuscus in the TNAL region. Tobelo tribal community hunts cuscus for variety purposes, among others, is used as an addition to the family's economic livelihood, to be consumed as a source of protein, for traditional medicine, and for use in traditional ceremonies (Taylor 1990). This study aimed to describe the traditional knowledge of Tobelo Dalam tribal community in Saolat village in the system of utilization and local conservation towards cuscus.

\section{MATERIALS AND METHODS}

\section{Study area}

The research was conducted in Saolat Village, South Wasile Sub-district, East Halmahera District, North Maluku (North Moluccas) Province, Indonesia (Figure 2).

\section{Procedures and data analysis}

The study was carried out in June to July 2015. The method of this research is qualitative method with explorative survey technique, interview, using a structured questionnaire. The survey covers identification (Flannery 1997) and inventory of cuscus species (Phalangeridae) which are exploited by the traditional community including the way they get cuscus (time, the tools, and condition of cuscus whether alive or dead), domesticating, benefits, and traditional conservation. The ethnozoology data source were obtained from key informants and respondents. The selection of key informants is based on snowball sampling technique while the selection of respondents uses purposive sampling technique (Tremblay 1957; Neuman 2003). This study used 50 respondents consist of 25 adult males and 25 females. There were 4 key informants consist of 3 males, 1 female to get additional information to complement the primary data obtained from the direct interview.

\section{RESULTS AND DISCUSSION}

\section{Traditional knowledge of Tobelo Dalam tribal community towards cuscus life}

Naturally males and females have the different attitude in dealing with problems so that they come into different knowledge and decision (Somnasang and Moreno-Black 2000). The same condition also happens in the social life of the Tobelo Dalam tribal community that live in Saolat village, district of South Wasile.

To have a better understanding about the concept of Tobelo Dalam tribal community in a Saolat village about cuscus life, there are nine questions should be answered by male and female respondents. The nine questions are as follows: (i) the history of cuscus name, (ii) knowledge of local name for cuscus, (iii) knowledge of cuscus characteristics, (iv) classification of cuscus, (v) habitat, (vi) types of food, (vii) predator, (viii) animals which harmless for cuscus, (ix) the distribution in Halmahera. All questions are interesting to investigate since the basic knowledge of cuscus life which can reflect the utilization and traditional conservation done by Tobelo Dalam tribal community.

The result of the questionnaire and interview on the traditional knowledge of cuscus present in Figure 3. In general, from the nine parameters measured which become the basic knowledge of characteristics of conscious life, if the difference in each parameter between males and females was presented as percentage, the average results show that males had an average percentage of traditional 
knowledge $69.1 \%$ while females had $30.9 \%$, so males had an advanced knowledge about $38.3 \%$ than females. It is understood since the males are as the householder who have responsibilities to fulfill family needs while females in social structure tend to be a managerial controller in the family. Male activities in the Tobelo Dalam tribal community go to the forest to crop plants near TNAL. Forest is the comfort and safe habitat for cuscus and it cannot be avoided that they often encounter cuscus sometimes they hunt cuscus to consume or sell it.

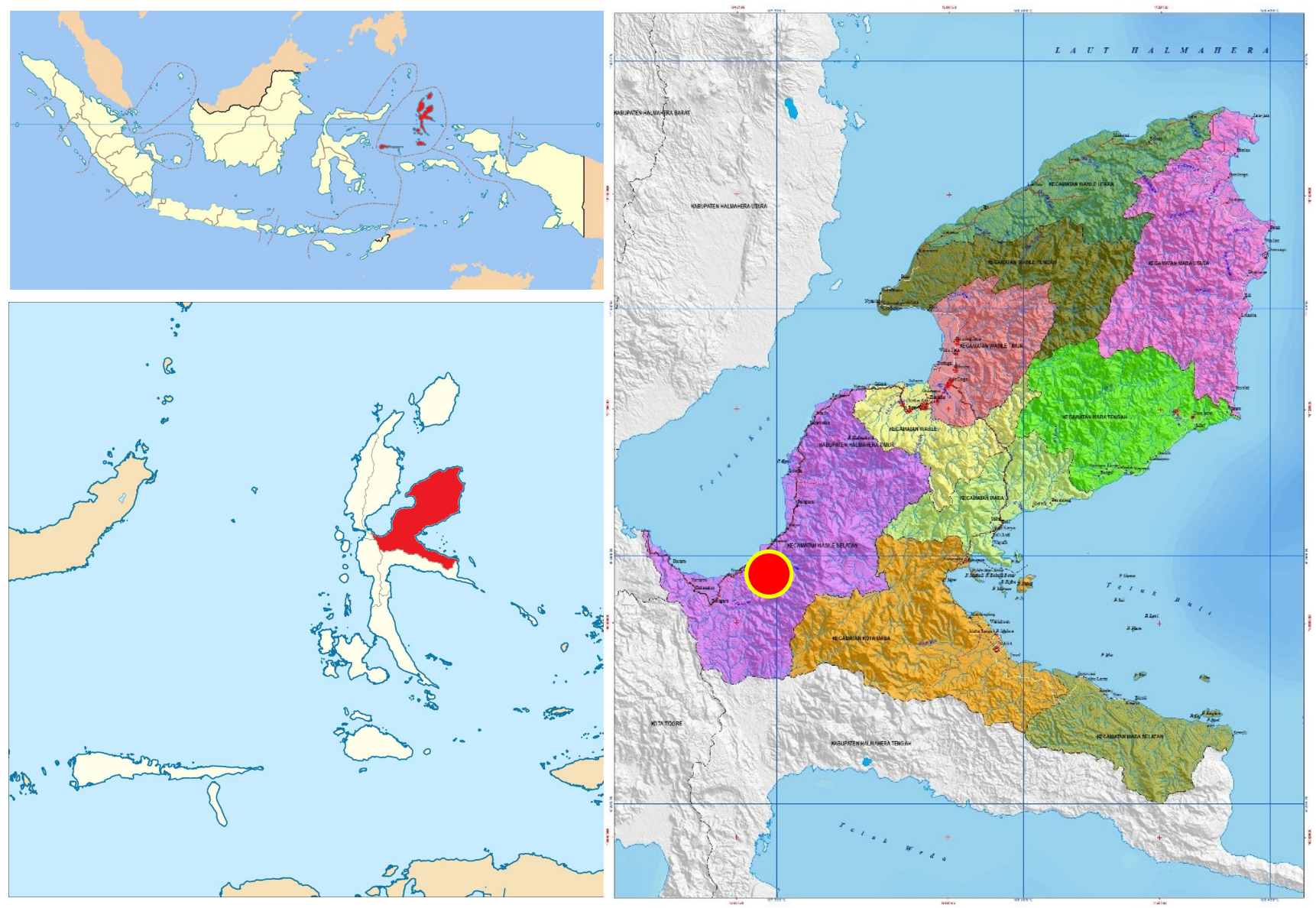

Figure 2. Map of research location in Saolat Village (O), South Wasile Sub-district, East Halmahera District, North Maluku (North Moluccas) Province, Indonesia

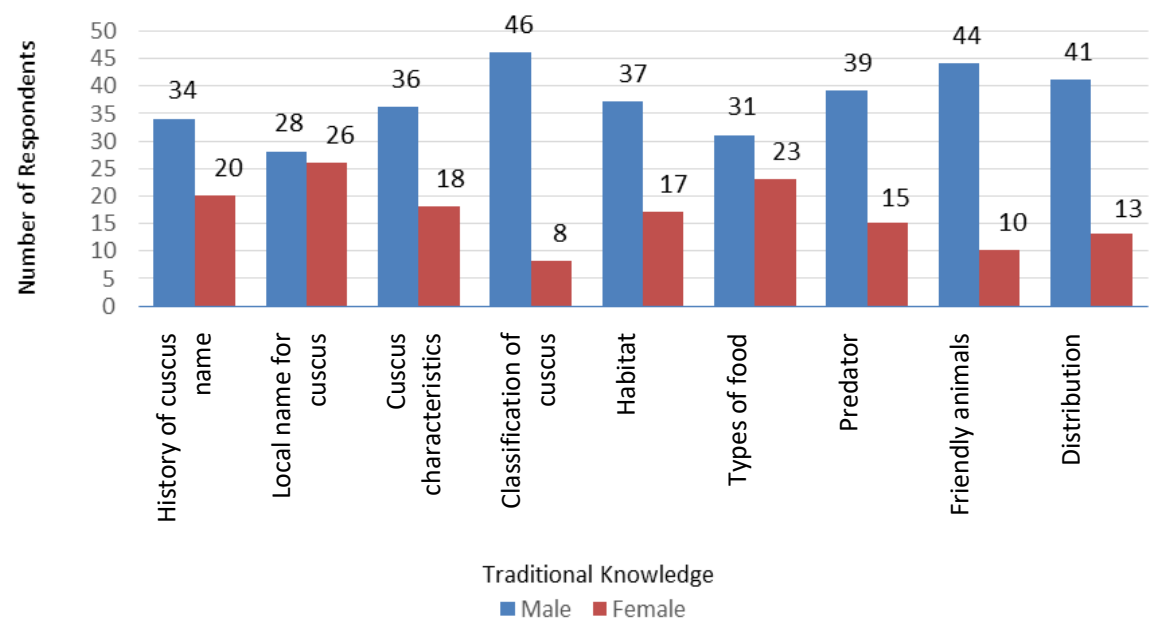

Figure 3. The result of assessment of traditional knowledge of Tobelo Dalam tribal community towards cuscus 
Some knowledge about cuscus owned by males become advantaged and show significantly higher $(\geq 50 \%)$ towards females among others knowledge of cuscus characteristics, animals grouping, habitat, predator, animals which harmless for cuscus, and the distribution in Halmahera (Figure 3). Males described cuscus as an animal which has a pouch in its tummy, legs with sharp claws, and strong tails, while based on its activity, cuscus is a nocturnal animal. According to the male respondents, cuscus inhabitants in forests, plantation nearby forests, and around river bank. Generally, most cuscuses live entirely in the canopy of trees in dense woodlands or plantation. The types of trees that become cuscus nests among others are pisang bole (Musa spp.), bido bidoho (Piper aduncum), lukama (Lansium domesticum), ngaeke (Pometia pinnata), luka lukama (Aglaia sp.), and rukiti (Gnetum gnemon) (Taylor 1990). The cuscus also lives in the wild mampuduar (Ficus virens) and mojiu (Barringtonia asiatica), ampupu (Eucalyptus urophylla), Pterocymium tinetorium, Aphanamyxis polystachya, Kleinhovia hospita, and Grewia koordersiana (Farida et al. 2005), matoa tree (Pometia pinnata) or coconut (Cocos nucifera) to become the choice of cuscus nest is quite comfortable and safe (Pattiselanno 2007). Males recognize that dudiha, snake (Python reticulatus) and koyoba ngulu ngulu, eagle (Accipiter henicogrammus) are the main predator of cuscus while bat (Fooradoxous sp.) is recognized as harmless for cuscus since they are often found eating fruits side by side. Males are more aware and understand about the distribution of cuscus in Halmahera; the areas are Tomares, Binagara, Ekor, Buli, Maba, Weda, Wasile, and other regencies which are in the Halmahera administration.

Males and females have the same understanding of the way they call cuscus in Tobelo language that is kuho or kuso. Most females have an understanding of cuscus life, not in detail but only to know the name and how to cook it, except a few females who are shaman medicine or traditional birth shaman attendants because they often go to the forest to look for plants as traditional medicine.

\section{The exploitation of cuscus by Tobelo Dalam tribal community}

The perspective of Tobelo Dalam tribal community in Saolat village both males and females towards the exploitation of cuscus in their daily lives has no difference. The community knowledge towards the exploitation of cuscus came from their ancestors which passed it generation to generation up to now. This information is clarified to key informants as a resource for traditional knowledge about cuscus. Generally, the community exploits cuscus for several needs i.e., a) traditional ceremonies, b) traditional medicine, c) cuisine, d) more income to support the economic of families.

\section{Traditional ceremonies}

Tobelo Dalam tribal community in Saolat village is mostly Christian and recognizes and carries along traditional ceremonies namely marriage, welcoming new year, and end of the year.
Traditional marriage ceremony (yoiyaka). The ceremony is conducted by family who has grown up daughters (mahoka), and they have future husbands. The ceremony takes place in bridegroom's house or church. The marriage blessing is led by the village elder and to complete the ceremony cuscus cuisine with 'rw' spices (Manadonese: rintek wu'uk meaning smooth fur). Cuscus is not the only animal which becomes one of the requirements of a rightful of the ceremony, there are several animals such as deer (Cervus timorensis), boar (Sus scrofa), chicken, biawak air (Hydrosaurus warneri), and biawak darat (Varanus sp.) that are also cooked and served. The ceremony aims to preserve tradition, to strengthen the family bound, and to build a new and happy family that is in harmony and blessed by God.

Welcoming new year ceremony. The ceremony is carried out by all Tobelo Dalam tribal community in the village hall or an open tent led by the village elder. The purpose of the ceremony is to ask for blessings and God's guidance throughout the year and be departed from harm and danger. Cuscus cuisine becomes the complement of the ceremony, other cuisines from different animals such as boar, deer, bat (Fooradoxous sp.) and fish are also cooked and served. There are local dances such as ronggeng, cakalele, and tide-tide.

End of the year ceremony. The ceremony is not different from the welcoming year ceremony even the leader and the place of the ceremony are the same. The difference is in the purpose of the ceremony. In this ceremony, the purpose is to give thanks to God for His blessing and guidance throughout the year. The same cuisines are also served in the ceremony.

In three ceremonies, Tobelo Dalam tribal community consumes cuscus 7 to 11 in each ceremony.

\section{Traditional medicine}

In the social life of Tobelo Dalam tribal community, cuscus is used to cure the community who has back pain and often used as vitality supplement in order to have energy to climb coconut trees. Several organs taken from cuscus are foot, hand, and tail bones. The treatment is the three kinds of bones mentioned are burnt and then pounded into powder then mix with coconut oil, scrub it to the back pain area or palm and foot when they climb the tree.

\section{Cuisine}

Humans have used wildlife as food since prehistory, one of the most basic uses of animals are to meet nutritional needs (Leakey 1981; Milner-Gulland et al. 2003; Schenck et al. 2006; Nasi et al. 2008; Sponheimer and Dufour 2009). Some ethnic groups in the Malinau watershed, North Kalimantan are known to use the highest wildlife for animal protein needs (Meijaard et al. 2005), as well as the Tobelo tribal community in consuming cuscus meat to eat as an added protein nutrition other than those from other animals such as monitor lizards, bats, crabs, and shells.

Cuscus is cooked with spices such as cooking 'rw' and served with rice at lunch or dinner. In order to cook cuscus, 
the meat is cut into small pieces and put into a pan to be seasoned with salt, lemon, lemongrass, and galangal, finally it is boiled.

\section{More income to support economic of families}

Hunting is one of the oldest activities carried out by humans with a variety of purposes, including reasons for the use of animals to defend against large predators (Alves 2012). Hunted animals are used in many ways, especially as food, but also as clothing and tools, and for medicinal and religious-magic purposes (Alvard et al. 1997; Child 2000; Alves and Pereira Filho 2007; Alves et al. 2009, Inskip and Zimmermann 2009). Hunting activity has become the part of Tobelo Dalam tribal community daily lives apart from other livelihoods such as fisher, copra farmer. This activity is carried out when unable to find fish. In general, they hunt animals that live around TNAL forests and among animals that are hunted are deer (Cervus timorensis), boar (Sus scrofa), monitor lizards, bats, and cuscus. The Tobelo Dalam tribal community does not recognize any prohibition on hunting at locations considered sacred or at certain times or sasi as in other tribes in the Kei Islands, Maluku, namely Yot in Kai Besar and Yutut in Kai Kecil or the Tepra tribe in Depapre, Papua with mythical traditions, namely an unwritten knowledge to regulate, manage, utilize and participate in conserving marine and coastal resources. The sasi system is another example of the cultural framework for managing resources.

People get cuscus by hunting in the forest or community gardens adjacent to the forest. They use simple hunting equipment such as bamboo pieces as a tool to lure cuscus to come closer so that they can easily catch it and occasionally while calling cuscus by imitating their voices or by placing traps on trees which are often as cuscus foraging places.

Mostly they hunt animal such as are deer, boar, lizard, bat, and cuscus which are in forest in TNAL.. Cuscus hunting activities are usually carried out by the Tobelo Dalam tribal community during the night from 07: 00 p.m. to 01: 00 a.m. or until morning at 05: 00 a.m. Hunting is carried out at the night because cuscus is a nocturnal animal which has activity in the night (Pattiselanno 2007). Cuscus tends to be found in conditions after rain and when the moon is bright because after the rain cuscus usually starts to look for food. When bright, the cuscus uses moonlight to find food sources. Hunting activities of the Tobelo Dalam tribe as well as the Rimba in Jambi, and some ethnic groups in Papua are carried out in a group of 2-5 people. The purpose of hunting carried out in groups is when obtaining large-sized animals those animals can be easily transported and enjoyed together. The activities carried out together show an indicator of the realization of cooperation and spirit of mutual assistance. When getting a cuscus that has a child, the child is then kept from the age of still tillers to adulthood. The equipment to hunt cuscus is still traditional and simple, namely machete (bamboo made specifically to call cuscus). Some of the community raises cuscus from newborn up to adult. The community sells cuscus to fulfill their daily needs (Hurtado-Gonzales and Bodmer 2004). They sell it to traditional markets nearby with various prices depend on its type and size. The price is about Rp 30.000 to Rp 50.000 each.

\section{Traditional conservation towards cuscus by Tobelo Dalam tribal community}

The sacred of a place has the essence of utilizing biodiversity resources in sustainable use for instance water supply, the availability of plants for food and medicines and animals as an alternative food source. Prohibitions or taboos related to cultural beliefs or practices are considered as local wisdom among ethnic groups (Madhusudan and Karanth 2002). According to Hill and Padwe (2000), Leuwenberg and Robinson (2000), traditional social taboos are protective against the practice of uncontrolled use of certain animal species. Such taboos can spread in several regions, or be limited to certain ethnic groups, clans or families (Bennett and Robinson 2000). As the Tobelo Dalam tribal community in Saolat Village, especially come from Bane family. According to key informants, around 15 percent of the population of the village is named Bane.. The community of Bane's family has beliefs passed down orally from generation to generation from their ancestors that cuscus is the ancestor of their ancestors, so there is a strict prohibition not to encounter, smell, or even consume its meat. In general, they obey the prohibition of the elders due to a sense of respect for their traditional beliefs, but some people obey the rule because of fear of the sanctions they get if they dare to break it. Bane family, wherever they will avoid meeting the cuscus. Members of Bane family indirectly preserve the existence of cuscus in the forests of the TNAL region in order to survive in a sustainable way.

It is also done and preserved by woven craftsmen and some kitchen appliances in Saolat village, they indirectly also preserve the existence of cuscus from the routine of harvesting activities of pandan duri leaves or pandan tikar or pandan samak or pandan pudak (Pandanus tectorius) which grow in the forest as a woven material. Usually, they make woven pandan leaves into a mat, kokoya, a container for harvesting rice, keeping rice, wrapping burning coals from the stove and making caping (headgear). They realize that their lives depend on the availability of pandan leaves, therefore sometimes they also preserve and keep the pandanus plant so as not to extinct by just taking it as necessary. The craftsmen also understand if the pandan plants are often used by the cuscus as a shelter because of their thorny leaves when in dangerous conditions such as the threat of attack from snakes or eagles.

However, the Tobelo Dalam tribal community also realizes that some of their life behaviors do not show the ethics of partiality in cuscus conservation. Some of the characters of the people who are still considered to be less supportive of this include: referring to the utilization of cuscus in the social life of Tobelo Dalam tribal community, mathematically it becomes a deep concern that in one year there are around 50 cuscuses are consumed by the community. While the reproduction of cuscus is low because within one year of reproduction the mother gives birth only one baby (Menzies 1991). It becomes our concern the sustainability of cuscus life if we have not done conservation. Although cuscus has long been declared an 
animal protected by Law No. 05 of 1990 concerning the Conservation of Biological Resources and their Ecosystems, and Government Regulation No. 07/1999 concerning the Conservation of Plants and Animal Species, but in general the Tobelo Dalam tribal community do not understand this information much, so that until now they are still using it to fulfill their living needs.

There is also a possibility that the people in Saolat Village have the view that the availability of cuscus in the forest is still quite a lot, this is indicated from the selling price of cuscus which is relatively much cheaper than in other Maluku towns such as in Ambon, so it seems cuscus easily obtained. Based on this problem, it is necessary to conserve the cuscus by building an understanding of the concern and importance of the existence of cuscus in the life of the Tobelo Dalam community through various educational approaches.

One way for people to understand and care about the importance of Law No. 5 of 1990 and PP No. 07 of 1999, it is necessary to conduct counseling on this matter to the customary leader, the elders, and the community by BKSDA officers. In order for the conservation activities being more comprehensive, it is also necessary to involve young people from the level of education in elementary, middle and high schools in supporting the sustainability of this cuscus life. This activity is carried out through counseling or distributing leaflets to schools about various information about cuscus life, including: character, a place of life, food sources, animals that become enemies, their conservation status, and constraints that can lead to a decrease in the number of cuscus population. Local knowledge can also be integrated into the school curriculum through formal science so that it becomes an important aspect in its further development (Basha et al 2012). It is hoped that from all of these activities, it can motivate and encourage people's behavior to not be consumptive of cuscus meat and be able to develop a stronger instinct for love than to kill these protected animals. Local knowledge and modern science complement each other to support conservation activities going well (Zhihong 2003).

In conclusion, Tobelo Dalam tribal community in Saolat village, district South Wasile, East Halmahera District has delivered different perception and concept between males and females in dealing with cuscus knowledge. Males have a better understanding of the knowledge than females. The Tobelo Dalam tribal community uses cuscus to fulfill various needs of their lives. Some of the Tobelo Dalam tribe community is involved in traditional species conservation for the sustainability of cuscus in TNAL forests. For example, by harvesting pandan leaves to taste, lush Pandanus is one of the protections for cuscus, and taboo which applies to the Bane family. But a greater threat has been waiting because the people are relatively consumed towards cuscus. Every year around 50 cuscus are killed for various purposes in their social life. Because of the high number of cuscus hunting, the local government should pay attention and make concrete actions to enhance conservation programs. The local government can use various kinds of approaches such as education and direct practices in the community so the people will change their lifestyle to be more aware about the need to conserve cuscuses in the study area.

\section{REFERENCES}

Alvard MS, Robinson JG, Redford KH, Kaplan H. 1997. The sustainability of subsistence hunting in the neotropics. Conserv Biol 11: 977-982.

Alves RRN, Pereira Filho GA. 2007. Commercialization and use of snakes in North and Northeastern Brazil: implications for conservation and management. Biodivers Conserv 16: 969-985.

Alves RRN, Mendonça LET, Confessor MVA, Vieira WLS, Lopez LCS. 2009. Hunting strategies used in the semi-arid region of northeastern Brazil. J Ethnobiol Ethnomed 5: 1-50.

Alves RRN. 2012. Relationships between fauna and people and the role of ethnozoology in animal conservation. Ethnobiol Conserv 1: 1-69.

Alves RRN, Souto WMS. 2015. Ethnozoology: a brief introduction. Ethnobiol Conserv 4 (1): 1-13

Basha SK, Gudivada S, Dalazak P, Ammnish V. 2012. Conserving Biodiversity of Yerramalais of Kurnool District, Andhra Pradesh, India, through People's Biodiversity Registers Program. Biodiv J 3 (2): 111-118.

Bennett EL, Robinson JG. 2000. Hunting of wildlife in tropical forestsimplications for biodiversity and forest peoples. Environment Department working papers no 76. Biodiversity Series. The World Bank, Washington DC.

BPS East Halmahera District. 2017. East Halmahera District in numbers. BPS, East Halmahera District. [Indonesian].

Child B. 2000. Making Wildlife Pay: Converting Wildlife's Comparative Advantage Into Real Incentives for Having Wildlife in African Savannas, Case Studies from Zimbabwe and Zambia. In: Prins HHT, Grootenhuis JG, Dolan TT, (eds). Wildlife Conservation by Sustainable Use. Conservation Biology Series 12. Springer, Dordrecht.

Farida WR, Triono T, Handayani TH, Ismail. 2005. Feed plants selection and nesting site of cuscus (Phalanger sp.) in nature reserve of Gunung Mutis, East Nusa Tenggara. Biodiversitas 6 (1): 50-54. [Indonesian]

Flannery TF. 1997. Mammals of Maluku. In: Monk KA, De Fretes Y, Reksodiharjo, Lilley G. (eds.). The Ecology of Nusa Tenggara and Maluku, Periplus Ltd, Singapore.

Hill K, Padwe J. 2000. Sustainability of ache hunting in the mbaracayu reserve, Paraguay. In: Robinson JG, Bennett EL, (eds.). Hunting for Sustainability in Tropical Forests. Columbia University Press, New York.

Helgen KM. 2007. Taxonomic and geographic overview of the mammals of Papua. In: Andrew JM, Beehler BM (eds) The Ecology of Papua. Part 1. Periplus Ltd, Singapore.

Helgen KM, Flannery TF. 2004. Notes on the phalangerid marsupial genus Spilocuscus, with the description of a new species from Papua. J Mammal 85 (5): 825-833.

Heinsohn TE. 1998. The Realm of the Cuscus: Animal Translocation and Biological Invasions East of Wallace's Line. [Thesis], Australian National University, Canberra.

Hunn ES. 2011. Ethnozoology. In: Anderson EN, Deborah MP, Eugene SH, Nancy JT (eds). Ethnobiology. John Wiley \& Sons, Inc, New Jersey.

Hurtado-Gonzales JL, Bodmer RE. 2004. Assessing the sustainability of brocket deer hunting in the Tamshiyacu Tahuayo communal reserve, Northeastern Peru. Biol Conserv $116: 1-7$.

Inskip C , Zimmermann A. 2009. Human-felid conflict: a review of patterns and priorities worldwide. Oryx 43: 18-34.

Latinis K. 1996. Hunting the cuscus in western Seram: the role of the Phalanger in subsistence economies in central Maluku. Cakalele 7: 17-32.

Leakey RE. 1981. The Making of Mankind. $1^{\text {ed }}$. Dutton, New York

Leuwenberg FT, Robinson JG. 2000. Traditional management of hunting in a Xavante community in Central Brazil: the search of sustainability. In: Robinson JG, Bennett EL (eds.) Hunting for 
Sustainability in Tropical Forests. Columbia University Press, New York. pp. 375-394.

MacDonald AA, Hill JE, Boeadi, Cox R. 1993. The mammals of Seram with notes on their biology and local use. In: Edwards ID, MacDonald AA, Proctor J. (eds.). Natural History of Seram Maluku, Indonesia. Andover Intercept Ltd., UK.

Madhusudan MD, Karanth KU. 2002. Local hunting and the conservation of large mammals in India. Ambio 3 (1): 49-54.

McNab BK. 2008. The comparative energetics of New Guinean cuscuses (Metatheria: Phalangeridae). J Mammal 89 (5): 1145-1151.

Milner-Gulland EJ, Bennett EL, Abernethy K, Bakarr M, Bodmer R, Brashares J, Cowlishaw G, Elkan P, Heather P, Peres C, Roberts P, Robinson J, Rowcliffe M, Wilkie D. 2003. Wild meat: the bigger picture. Trends Ecol Evol 18 (7): 351-357.

Meijaard E, Douglas S, Robert N, David A, Barry R, Djoko I, Titiek S, Martjan L, Ike R, Anna W, Tonny S, Scott S, Timothy O. 2005. Life after logging Reconciling wildlife conservation and production forestry in Indonesian Borneo. CIFOR and UNESCO. Indonesia.

Menzies JI. 1991. A Handbook of New Guinea Marsupials and Monotermes. Kristen Press Inc. Papua New Guinea, Madang.

Nasi R, Brown D, Wilkie D, Bennett E, Tutin C, van Tol G, Christophersen T. 2008. Conservation and use of wildlife-based resources: the bushmeat crisis. Secretariat of the Convention on Biological Diversity, Montreal, and Center for International Forestry Research (CIFOR), Bogor.

Nowak RM. 1999. Walker's Mammals of the world. $6^{\text {th }}$. The Jhon Hopkins University Press. Baltimore.
Neuman WL. 2003. Social Research Methods Quaitative and Quantitative Approaches ( $5^{\text {th }}$ eds.). Allyn and Bacon, USA.

Pattiselanno F. 2007. Cuscus (Phalangeridae) hunting by Napan communities at Ratewi Island, Nabire, Papua. Biodiversitas 8 (4): 274-278. [Indonesian].

Saluang S. 2014. Deprivation of Living Space through the Body Approach. Bogor. Sajogyo Institute Working Paper No. 7/2014. Sajogyo Institute. [Indonesian].

Schenck M, Nsame Effa E, Starkey M, Wilkie D, Abernethy K, Telfer P, Godoy R, Treves A. 2006. Why people eat bushmeat: results from two-choice, taste tests in Gabon, Central Africa. Hum Ecol 34: 433445.

Somnasang P, Moreno-Black G. 2000. Knowing, gathering and eating: Knowledge and attitudes about wild food in an Isan village in Northeastern Thailand. J Ethnobiol 20 (2): 197-216.

Sponheimer M, Dufour DL. 2009. Increased dietary breadth in early hominin evolution: revisiting arguments and evidence with a focus on biogeochemical contributions. In: Hublin JJ, Richards MP (eds) The Evolution of Hominin Diets: Integrating Approaches to the Study of Paleolithic Subsistence. Springer, Heidelberg.

Taylor PM.1990. The Folk Biology of the Tobelo People: A Study in Folk Classification. Smithsonian Institute Press, Washington D.C.

Tremblay MA. 1957. The Key Informant Technique: A Non Ethnographic Application. Am Anthropol 59 (4): 688-701.

Zhihong B. 2003. Indigenous knowledge and development. Landscapes of diversity indigenous knowledge, sustainable livelihoods and resource governance in Montane Mainland Southeast Asia, Proceedings of the $3^{\text {th }}$ Symposium on MMSEA, CBIK, Kunming Yunnan. 